\title{
COMUNICAÇÃOCIENTÍFICA
}

\section{GRAFTING OF QUINCE 'PORTUGAL' ON Cydonia AND Chaenomeles ROOTSTOCKS ${ }^{1}$}

\author{
RAFAELPIO ${ }^{2}$, EDVAN ALVES CHAGAS ${ }^{3}$, WILSON BARBOSA ${ }^{4}$, ÂNGELO ALBÉRICO ALVARENGA $^{5}$, \\ ENILSON ABRAHÃO ${ }^{5}$, NELSON PIRES FELDBERG ${ }^{6}$, ANTÔNIO FERNANDO CAETANO TOMBOLATO $^{4}$
}

\begin{abstract}
In the specific case of the quince trees, there is lack of information about the emergency of their seedlings, development and time of production of rootstocks to reach the point of the grafting, as well as development of the grafts. Therefore, the objective of the present research was to study the Cydonia and Chaenomeles genera, as well as the development of the grafts during the nursery phase. Seeds of the quince tree cultivars 'Mendoza Inta-37', 'Provence', 'Portugal' and 'Japonês' were obtained from ripe fruits and submitted to cold stratification during 20 days. Soon after, the seeds were sowed in 72 -cell polystyrene trays $\left(120 \mathrm{~cm}^{3}\right.$ of capacity/cell) containing vermiculite as substrate. After 60 days, the seedlings were put in plastic bags ( 3 liters of capacity) filled with a substrate containing soil: sand: manure $(1: 1: 1 \mathrm{v} / \mathrm{v})$. The seedlings were kept in a $50 \%$ of shadow nursery and periodically irrigated. After 180 days, the seedlings were grafted by the cleft grafting method, during the winter, using scion sticks from quince 'Portugal'. After 60 days, the percentage of alive and sprouted grafts was evaluated. The length and diameter of the grafts were measured every 30 days, a total of four times. The quince 'Japonês' showed the best performance among all the rootstocks in this experiment, being an excellent alternative as rootstock for quince trees. 'Japonês' and 'Mendoza Inta-37' were also the rootstocks that promoted the best development of the grafts.
\end{abstract}

Index Terms: Cydonia oblonga Mill.; Chaenomeles sinensis Koehne; propagation; intergeneric grafting.

\section{ENXERTIA DO MARMELEIRO ‘PORTUGAL’EM PORTA-ENXERTOS Cydonia e Chaenomeles}

RESUMO - Com relação ao marmeleiro, há carência de informações sobre a emergência das plântulas, desenvolvimento e tempo de produção dos porta-enxertos, assim como o desenvolvimento do enxerto. O objetivo do presente trabalho foi estudar o comportamento de marmeleiros do gênero Cydonia e Chaenomeles em relação ao desenvolvimento dos enxertos, em condições de viveiro. Sementes do marmeleiro 'Mendoza Inta-37', 'Provence', 'Portugal' e 'Japonês', foram extraídas de frutos maduros e estratificadas à frio por 20 dias. Em seguida, foram semeadas em bandejas de poliestireno ( 72 células, capacidade de $120 \mathrm{~cm}^{3}$ por célula), contendo a vermiculita como substrato. Posteriormente, as plântulas foram transplantadas em sacos plásticos (capacidade de $3 \mathrm{~L}$ ), contendo terra + esterco de curral curtido + areia $(1: 1: 1 \mathrm{v} / \mathrm{v})$, como substrato. As plântulas permaneceram em viveiro sombreado (50\% de luminosidade) e foram irrigadas sistematicamente. Depois de 180 dias do transplantio, as plântulas foram enxertadas pelo processo de garfagem, durante o inverno, com garfos do marmeleiro 'Portugal', sendo avaliado após 60 dias da enxertia, a porcentagem de enxertos brotados, assim como o comprimento e diâmetro do enxerto. As duas últimas variáveis foram avaliadas três vezes mais, a cada 30 dias. $\mathrm{O}$ marmeleiro 'Japonês' apresentou maior desempenho, demonstrando ser uma excelente alternativa como porta-enxerto para o marmeleiro e, junto como o 'Mendoza Inta-37', foram os que proporcionaram maior desenvolvimento do enxerto.

Termos para indexação: Cydonia oblonga Mill.; Chaenomeles sinensis Koehne; propagação; enxertia intergenérica.

\footnotetext{
${ }^{1}$ (Trabalho 238-07). Recebido em: 03-10-2007. Recebido para publicação em: 12-02-2008.

${ }^{2}$ Professor Adjunto D.Sc., Universidade Estadual do Oeste do Paraná - UNIOESTE. Rua Pernambuco, nº 1777, Caixa Postal 1008, Centro, 85960-000, Marechal Cândido Rondon-PR, Brazil. Bolsista produtividade em pesquisa CNPq.Author for correspondence: rafaelpio@hotmail.com

${ }^{3}$ Pesquisador Científico, D.Sc., Instituto Agronômico - IAC. Av. Luiz Pereira dos Santos, 1500, Corrupira, 13214-820, Jundiaí-SP, Brazil. echagas@iac.sp.gov.br Bolsista produtiviadade em pesquisa CNPq.

${ }^{4}$ Pesquisador Científico, D.Sc., Centro Experimental Central, Instituto Agronômico - IAC. Caixa Postal 28, 13001-970, Campinas-SP. Bolsista produtividade em pesquisa do CNPq. wbarbosa@iac.sp.gov.br

${ }^{5} E^{\circ}{ }^{\circ}$. Agrônomo, D.Sc., Pesquisador Científico da Empresa de Pesquisa Agropecuária de Minas Gerais - EPAMIG/CTSM. Campus da UFLA, Caixa Postal 176, Rodovia Lavras/IJACI, km 02, 37200-000, Lavras-MG. angelo@epamig.ufla.br

${ }^{6}$ Pesquisador Científico, M.Sc., Pólo APTA Regional Sudoeste Paulista. Rodovia Sebastião Ferraz de Camargo Penteado - SP 250 , Km 232 Caixa Postal 62, 18300-970, Capão Bonito-SP, Brazil.nelson.pires@aptaregional.sp.gov.br
} 
Among the temperate climate fruit species, the quince is, without any doubt, some of the most interesting and appreciated fruits all over the world, mainly because of its high pectin content. It is largely used in the production of marmalades, compotes and jellies. The quinces and the marmalade were one of the main and first products to be exported by Brazil. In the old world and in colonial Brazil, few fruits as quince had such importance, but, surprisingly, even nowadays it is a fruit species which lacks so much of information and studies about. The probable causes of that small interest can be a little reside in its only use as industrial raw material and its restricted consumption as fresh fruit (Pio et al., 2005a).

The quince constitutes a fruit of great importance in the world, especially for small farms, where the quince cultivation is an excellent alternative of high profitability. Some researchs of relevance were prioritized in Brazil in an attempt of revitalizing the national quince cultivation and, among those, the one of larger importance was the study about the use of the 'Japonês' quince cultivar (Chaenomeles sinensis Koehne) as rootstock for the other quince cultivars explored commercially in Brazil (all Cydonia oblonga Mill.) and even for pear trees and loquat trees (Abrahão et al., 1991; 1996).

In the sense of defining the propagation protocol for the 'Japonês' cultivar, some researchs involving the vegetative propagation were carried out, however, there was no success in rooting its cuttings (Pio et al., 2004a; 2004b; 2005b).

Through sexual propagation, it was verified that the seeds show high germination and the seedlings provide good performance in the field as rootstocks for some quince cultivars (Abrahão et al., 1995; 1996). However, there is lack of information about the seedlings emergency, development in the nursery and necessary time for the seedlings to reach the grafting point. Besides, it would be interesting to compare with other quince trees used commercially in Brazil, mainly in the production of rootstocks and development of the grafts, to verify the real potentialities of the quince 'Japonês', once it is a different genus from the others.

Therefore, the objective of the present research was to study the genera Cydonia and Chaenomeles, as well as the development of the grafted cultivars onto them in the nursery.

The experiments were developed at the Instituto Agronômico - IAC, Fruticulture Center, located in Jundiaí city, São Paulo State - Brazil, from May 2005 to December 2006.

Fruits were collected from the following quince cultivars: 'Mendoza Inta-37', 'Provence', 'Portugal', all belonging to the species Cydonia oblonga Mill., and 'Japonês' (Chaenomeles sinensis Koehne). The mother plants were eight years old and they were located at the IAC temperate climate fruit collection. The seeds were extracted and rinsed in running water, and dried under shade for 48 hours. After that, they were submitted to cold stratification in boxes with sand (BOD, at $4^{\circ} \mathrm{C}$ ) for 20 days. Soon after, the seeds were sowed in 72-cell polystyrene trays $\left(120 \mathrm{~cm}^{3}\right.$ of capacity/cell) containing medium granuled vermiculite as substrate.

After 60 days, the seedlings were put in plastic bags (3 liters of capacity) filled with a substrate containing soil: sand: manure $(1: 1: 1 \mathrm{v} / \mathrm{v})$. The seedlings were kept in a $50 \%$ of shadow nursery and periodically irrigated.

Later, the seedlings stayed in the nursery for seven months and were grafted in the winter, in the middle of July, with $65 \mathrm{~cm}$ of minimum height and around $7 \mathrm{~mm}$ of diameter. The experiment, a completely randomized design was used, with four replications of 10 rootstocks per plot. The rootstocks were grafted by the cleft grafting method, using 'Portugal' scion sticks with three buds each. The grafts were tied by plastic ribbon and protected with transparent plastic bags covering the scion sticks for 30 days ( $15 \mathrm{~cm}$ of length and $3 \mathrm{~cm}$ of diameter). Sixty days after grafting, the sprouting percentage, length and diameter of the grafts were evaluated. The evaluations of the last two parameters were repeated for more three times every 30 days.

The data were submitted to the analysis of variance, and the means compared by Tukey's test at $5 \%$ of significance level. The analyses were accomplished using the program SISVAR (Ferreira, 2000).

For the evaluation of the grafts development, it was noticed that in spite of no statistic differences for the percentage of sprouted grafts 60 days after grafting, 'Portugal' presented $93.3 \%$ of success as rootstock, what was already expected, once the same cultivar was grafted onto it (Table 1); the others presented high indices, but for 'Japonês' only 65\%. Future experiments will be done aiming to define better periods and grafting techniques to increase these results.

In the first two evaluations of the sprouts average length, there was no difference among the rootstocks, but in the third and fourth evaluation after 120 and 150 days of the grafting, the quince cultivars 'Japonês' and 'Mendoza Inta-37' showed a longer grafts development (Table 1). Consequently, the grafts diameter was also superior when using 'Japonês' and 'Mendoza Inta-37' as rootstocks (Table 2).

By this data, it can be verified the importance of the use of vigorous rootstocks, as 'Japonês' and 'Mendoza Inta-37', with faster grafts development and consequently, time reduction in nursery can be verified. This implicates a reduction of the seedlings costs, with a shorter time of permanence of this cultivars in the nursery and reduction of the expenses for the orchard implantation. Besides, possibly the vigor of 'Japonês' and 'Mendoza Inta-37' will influence the development and production of the plants in the field, which will be observed in the future.

It is worth to say that the seeds of 'Japonês' maintained high germination percentage and emergency in acceptable levels (Pio et al., 2007), showing similarity with the 'Taiwan Nashi-C' (Barbosa et al., 1997), most used as rootstock for pear trees.

High loss of quince seedlings from the Cydonia genus in the emergency phase was caused due to the high damping-off occurrence (Campo Dall'Orto et al., 1987), what was not observed for the 'Japonês', but noticed for the other cultivars. Possibly, it can be one of the causes of the superiority of 'Japonês'.

The quince 'Japonês' can be an excellent rootstock alternative for quince cultivars. It also promoted the best development of the grafts, what was observed for the grafts onto 'Mendoza Inta-37' too. 
TABLE 1 - Sprouted scion sticks percentage and average length of the scion sprouts in 60, 90, 120 and 150 days after grafting the 'Portugal' quince cultivar onto different rootstocks from the Cydonia and Chaenomeles genera. Jundiaí-SP, Centro APTAFrutas/IAC, Brazil, 2007.

\begin{tabular}{|c|c|c|c|c|c|}
\hline \multirow{2}{*}{$\begin{array}{c}\text { Quince rootstock } \\
\text { c ultivar }\end{array}$} & \multirow[b]{2}{*}{$\%$ sprouted } & \multicolumn{3}{|c|}{ Average length of the scion sprouts $(\mathrm{cm})$} & \multirow[b]{2}{*}{ days } \\
\hline & & 60 days & 90 days & 120 days & \\
\hline Japonês & $65.0 \mathrm{a}$ & $7.24 \mathrm{a}$ & $29.23 \mathrm{a}$ & 43.71 a & $45.27 \mathrm{a}$ \\
\hline M endoza & $82.5 \mathrm{a}$ & $10.12 \mathrm{a}$ & 29.84 a & $41.05 \mathrm{a}$ & $41.41 \mathrm{a}$ \\
\hline Provence & $75.0 \mathrm{a}$ & $8.53 \mathrm{a}$ & 28.26 a & 32.65 & 32.86 \\
\hline Portugal & $93.3 \mathrm{a}$ & $10.53 \mathrm{a}$ & $26.26 \mathrm{a}$ & 32.53 & 33.35 \\
\hline $\mathrm{cv}(\%)$ & 22.35 & 28.65 & 17.77 & 13.47 & 15.28 \\
\hline
\end{tabular}

* Means separation at 5\% level (DMRT). Means followed by the same letters in the columns do not differ significantly among themselves by the Tukey's test.

TABLE 2 - Average diameter of the scion sprouts in 60, 90, 120 and 150 days after grafting the 'Portugal' quince cultivar in different rootstocks from the Cydonia and Chaenomeles genera. Jundiaí-SP, Centro APTA Frutas/IAC, Brazil, 2007.

\begin{tabular}{|c|c|c|c|c|c|c|c|c|}
\hline \multirow[t]{2}{*}{ Quince } & \multirow[t]{2}{*}{ rootstock } & \multirow[t]{2}{*}{ cultivar } & \multicolumn{4}{|c|}{ Average diameter of the scion sprouts $(\mathrm{mm})$} & \multicolumn{2}{|r|}{$*$} \\
\hline & & & 60 days & 90 days & 120 & days & 150 & days \\
\hline Japonês & & & $1.40 \mathrm{a}$ & $3.37 \mathrm{a}$ & 4.63 & a & 5.03 & $\mathrm{a}$ \\
\hline$M$ endoza & Inta -37 & & $1.76 \mathrm{a}$ & $3.31 \mathrm{a}$ & 4.19 & a & 4.64 & a \\
\hline Provence & & & $1.44 \mathrm{a}$ & $2.99 \mathrm{~b}$ & 3.92 & $\mathrm{~b}$ & 4.18 & b \\
\hline Portugal & & & $1.79 \mathrm{a}$ & 2.68 & 3.76 & $\mathrm{~b}$ & 4.14 & $\mathrm{~b}$ \\
\hline $\operatorname{cv}(\%)$ & & & 20.78 & 9.63 & 960 & & 8.25 & \\
\hline
\end{tabular}

* Means separation at 5\% level (DMRT). Means followed by the same letters in the columns do not differ significantly among themselves by the Tukey's test.

\section{REFERENCES}

ABRAHÃO, E.; ALVARENGA, A.A.; SOUZA, M. Geminação das sementes do marmeleiro (Chaenomeles sinensis Koehne cv. Japonês). Ciência e Prática, Lavras, v. 19, n. 3, p. 342-343, 1995.

ABRAHÃO, E.; ALVARENGA, A.A.; SOUZA, M. Marmeleiro (Chaenomeles sinensis) cv. Japonês - Porta-enxerto para marmeleiros, pereiras e nespereiras. Revista Brasileira de Fruticultura, Jaboticabal, v. 13, n. 2, p. 181-182, 1991.

ABRAHÃO, E.; SOUZA, M.; ALVARENGA, A.A. A cultura do marmeleiro em Minas Gerais. Belo Horizonte: EPAMIG, 1996. 23 p. (Boletim Técnico, 47)

BARBOSA, W.; CAMPO DALL'ORTO, F.A.; OJIMA, M.; NOVO, M.C.S.S.; BETTI, J.A.; MARTINS, F.P. Conservação e germinação de sementes e desenvolvimento de plântulas da pereira porta-enxerto 'Taiwan Nashi-C'. Scientia Agrícola, Piracicaba, v. 54, n. 3, p. 147-151, 1997.

CAMPO DALL'ORTO, F.A.; OJIMA, M.; FERRAZ, E.S.B.; IGUE, T.; MARTINS, F.P.; RIGITANO, O. Germinação das sementes de marmelo: meios e períodos de estratificação e processos de preparo. Bragantia, Campinas, v. 46, n. 2, p. 315-328, 1987.

FERREIRA, D.F. Análise estatística por mei o do SISVAR (Sistema para Análise de Variância) para Windows versão 4.0. In: REUNIÃO ANUAL DA REGIÃO BRASILEIRA DA SOCIEDADE INTERNACIONAL DE BIOMETRIA, 45., 2000, São Carlos. Anais... São Carlos: UFSCar, 2000. p. 255-258.
PIO, R.; ARAÚJO, J.P.C.; SCARPARE FILHO, J.A.; MOURÃO FILHO, F.A.A.; ALVARENGA, A.A.; ABRAHÃO, E. Potencial de propagação de cultivares de marmeleiro por estaquia. Revista Brasileira de Fruticultura, Jaboticabal, v. 26, n. 2, p. 287-289, 2004a.

PIO, R.; CAMPO DALL'ORTO, F.A.; ALVARENGA, A.A.; ABRAHÃO, E.; BUENO, S.C.S.; MAIA, M.L. A cultura do marmeleiro. Piracicaba: ESALQ/USP, 2005a. 53 p. (Boletim Técnico, 29)

PIO, R.; CHAGAS, E.A.; BARBOSA, W.; SIGNORINI, G.; ALVARENGA, A.A.; ABRAHÃO, E.; CAZETTTA, J.O.; ENTELMANN, F.A. Emergência e desenvolvimento de plântulas de cultivares de marmeleiro para uso como porta-enxerto. Revista Brasileira de Fruticultura, Jaboticabal, v. 29, n. 1, p. 133-136, 2007.

PIO, R.; RAMOS, J.D.; CHALFUN, N.N.J.; GONTIJO, T.C.A.; CARRIJO, E.P.; TOMASETTO, F.; VISIOLI, E.L.; BETTIOLNETO, J.E. Enraizamento de estacas lenhosas dos marmeleiros 'Portugal' e 'Japonês' tratadas com ácido indolbutírico. Revista Ceres, Viçosa, v. 51, n. 298, p. 777-786, 2004 b.

PIO, R.; RAMOS, J.D.; CHALFUN, N.N.J.; GONTIJO, T.C.A.; CARRIJO, E.P.; MENDONÇA, V.; ALVARENGA, A.A.; ABRAHÃO, E. Enraizamento de estaca dos marmeleiros 'Portugal' e 'Japonês' em diferentes ambientes e posições no recipiente. Ciência e Agrotecnologia, Lavras, v. 29, n. 5, p. 968-973, 2005 b. 